\author{
Jadwiga Linde-Usiekniewicz $\odot$ https://orcid.org/0000-0002-7083-0486 \\ University of Warsaw, Faculty of Polish Studies
}

\title{
Wh+To Non-Restrictive Clauses in Polish and Related Phenomena. Part One. Wh vs. Wh-to Relative Clauses: An Overview ${ }^{1}$
}

\begin{abstract}
This paper presents a comparison between to-bearing relative clauses, adverbials and interrogatives on the one hand, vs. their to-less variants on the other, and discusses the functions associated with the presence of to. It is argued that at least three different instances of to should be distinguished. One converts relative clauses into appositive ones, which are necessarily semantically connected to the matrix clause and it makes the semantic connection override even apparent lack of appropriate syntactic connection. It attaches to relativizers, including gdzie 'where' and kiedy 'when' relative clauses. It is argued that the same segment is present in adverbials, triggering a factitive presupposition, as is the case of appositive relatives generally. The second to links the content of a kind relative, an adverbial or a $w h$-interrogative to previous contexts, possibly triggering a pragmatic presupposition. The third converts standard $w h$-interrogatives into either rhetorical or thetic questions. It is argued that while in the third instance we are dealing with a separate word and in the second with a clitic, the first to, hitherto unidentified or possibly falsely identified in relevant literature, appears to have both some characteristics of a clitic and of an affix.
\end{abstract}

\section{Keywords}

Polish relative clauses, appositive clauses, the segment to, presupposition triggers, thetic questions, rhetorical questions, clitics

\section{Streszczenie}

$\mathrm{W}$ artykule omawia się funkcje segmentu to w zdaniach względnych, zdaniach okolicznikowych i pytaniach uzupełnienia. Wykazuje się, że segment ten w wymienionych typach zdań odpowiada co najmniej trzem różnym jednostkom. Pierwsza z nich wskazuje, że mamy do czynienia ze zdaniem względnym niedefiniującym, ale koniecznie powiązanym semantycznie z treścią zdania głównego; co więcej, powoduje, iż zdania takie są akceptowalne, mimo niepoprawnej budowy składniowej. Najprawdopodobniej ten sam element może być dołączony - jako wyzwalacz presupozycji - do spójnika wprowadzającego zda-

\footnotetext{
${ }^{1}$ I would like to thank two anonymous SPL reviewers for their insightful comments and suggestions, and Daniel J. Sax for copy-editing my manuscript.
} 
nie okolicznikowe miejsca i czasu. Druga jednostka to wykładnik nawiązania, być może związany z presupozycją pragmatyczną, obecna w pytaniach uzupełnienia i w zdaniach względnych utożsamiająco-uogólniających. Trzecia jednostka natomiast, pojawiająca się w pytaniach, przekształca je w pytania retoryczne lub tetyczne. O ile ta ostatnia jednostka ma status wyrazu, o tyle wykładnik nawiązania wykazuje wszelkie własności wiązane z klitykami. Status pierwszej jednostki jest problematyczny, jako że wykazuje cechy zarówno klityki, jak i afiksu.

\section{Słowa kluczowe}

zdania względne w języku polskim, zdania niedefiniujące, segment to, wyzwalacze presupozycji, pytania tetyczne, pytania retoryczne, klityki

\section{Introduction}

This paper attempts to analyze a set of non-restrictive relative clauses in Polish that bear a to segment attached to the relativizer against a broader background of certain wh-to clauses. At least one of the subtypes of wh-to relative clauses has been overtly identified in the relevant literature (Topolińska 1984; Bańko 2013; Mendoza 2010; Dobaczewski 2018: 229; Linde-Usiekniewicz in print) - namely, non-restrictive relative clauses featuring an internal head in addition to an external one. In such clauses, to is obligatorily attached to the relativizer który.

(1) Za zasługi został nawet burmistrzem Cognac, który to urząd piastował przez ponad 20 lat. (Mendoza 2010: 1)

'In acknowledgment of his services, he was even made the mayor of Cognac, which office he held for over 20 years.' (transl. JL-U)

(2) Widziałem wczoraj moją dawną nauczycielkę, która to nauczycielka obecnie pracuje $w$ teatrze. (Topolińska 1984: 346, cited in Mendoza 2010)

'Yesterday I saw my former schoolmistress, which schoolmistress works now in a theater.' (transl. JL-U)

With the exception of Mendoza (2010), such non-restrictive relative clauses have been rather marginally treated and overlooked in the syntactic literature (see Linde-Usiekniewicz in print for discussion).

Even less attention, with the notable exception of Mendoza (2010), has been paid to the fact that the segment to can attach to który in appositive clauses, even in the absence of internal heads, though removing to does not lead to ungrammaticality. ${ }^{2}$ It may nevertheless result in a change in the interpretation of the relative clause. Thus (3) is appositive, while (4) is either restrictive or appositive (I will discuss the issue later on).

${ }^{2}$ According to Mendoza (2010: 8), który to in (3) represents the relative pronoun który with a modal particle to attached, not the relative pronoun który to. 
(3) Dawno, dawno temu, kiedy jeszcze w Warszawie byli cwaniacy, którzy to sprzedawali i most Kierbedzia i kolumnę Zygmunta, powstało powiedzenie: [... ] (Mendoza 2010: 8) 'A long, long time ago, when in Warsaw there were still conmen, who used to sell both the Kierbedź bridge and King Sigismund's Column, a saying was coined...' (transl. JL-U)

(4) Dawno, dawno temu, kiedy jeszcze w Warszawie byli cwaniacy, którzy sprzedawali i most Kierbedzia i kolumnę Zygmunta, powstało powiedzenie: [... ] (Mendoza 2010: 8) 'A long, long time ago, when in Warsaw there were still conmen who used to sell both the Kierbedź bridge and King Sigismund’s Column, a saying was coined...' (transl. JL-U)

The same author also rightly notes that to can attach (optionally) to interrogative pronouns, again with a subtle shift of meaning, noted by the author:

(5a) A dokad to idziesz? (Mendoza 2010: 8)

'And where are you going?'

(5b) A dokąd idziesz? (Mendoza 2010: 8)

'And where is it that you are going?'

Both corpus data and my own linguistic intuitions confirm that to can attach to a wider range of elements, which have a rather complex array of various syntactic functions. It attaches to all kinds of interrogative pronouns, as shown in (6), to their homonyms used as relativizers, cf. (7) and (8), as well as to their homonyms used as conjunctions introducing adverbial clauses, as shown in (9).

(6) Kiedy to ostatnio wygraliśmy u siebie? (NKJP)

'When was the last time we won at our home ground?' (transl. JL-U)

(7) Zeszłego lata, kiedy (to) Jan się urodzit, było bardzo ciepło.

'Last summer, when Jan was born, (it) was very warm'

(adapted from Citko 2016: 92)

(8) Nie chcę, by powtórzyła się sytuacja $z$ ubiegłego weekendu, gdzie to podczas upalnej niedzieli, tłumy miłośników kąpieli, korzystały z niej na Gliniaku w Bolęcinie. (NKJP) 'I don't want last weekend's situation to repeat, where during a hot Sunday crowds of bathing enthusiasts bathed in the Gliniak (quarry pond) in Bolęcin.' (transl. JL-U)

(9) Dziesięć lat temu trafit do Księgi Guinnessa, kiedy to jako jedyny 70-latek wykonat 201 stójek na rękach...(NKJP)

'Ten years ago he made it into the Guinness Book of Records, when as the only seventy-year-old he performed 201 handstands...' (transl. JL-U)

The segment to in który to has been classified as a linking marker (Polish: wykładnik nawiązania) by Topolińska (1984: 346) and by Mendoza (2010:7) as a part of the relativizer. Some interesting insights into the function of the to segment in questions come from Mendoza's (2010) informers, who link it to the speaker's perspective on what is being said. 
The relative clauses with który to are rightly recognized both by Mendoza (2010) and by Citko (2016) as non-restrictive relative clauses. Yet, in Polish, non-restrictive relative clauses can be formed with który alone, with the already mentioned exception of relative clauses with an internal head. One example, cited above in (4), comes from Mendoza (2010), others can be easily found in Citko (2016).

This paper will address several related questions. One is to identify the nature of the to segment appearing in all the examples given so far and in further instances discussed in Part Two. The main question is whether in all instances to represents the same element or not. In other words, are we dealing here with relativizers and/or interrogative pronouns to which to is appended to alter, albeit subtly, the semantics of a clause or even independent interrogative sentence, or are we dealing with distinct sets of function words, distinguished by the presence vs. absence of the sequence to, or is the situation somehow more complex? The second view seems to be espoused by Mendoza (2010: 7). With reference to który to in clauses with internal heads she writes:

The question how to analyze the complex który to in relative clauses with internal nucleus is relatively clear. Since the element to cannot be omitted in such constructions, the sequence który to must be interpreted as one unit. The expression is to be regarded as a separate lexeme, as another relative pronoun besides który, co etc. The element to then has the status of an affix, with which the relative pronoun is derived from the question pronoun który. (trans. JL-U) ${ }^{3}$

At the same time she seems to be in favor of treating all the other instances of attached to she discusses as featuring a separate particle.

The remainder of this part of the paper is dedicated to an overview of Polish relative clauses with and without to. Section 1 discusses types of relative clauses present in Polish. Section 2 focuses on a more fine-grained typology of appositive clauses in general. In section 3, the impact of to on the clauses presented in Section 1 is discussed, and specifically, it is shown that its role seems to be that of cancelling all readings but the appositive. In Closing remarks I will briefly sum up the findings presented in this part of the paper and announce the issues to be discussed in the second part of the paper, which discusses the presence of to after wh-conjunctions and wh-interrogative pronouns and presents an attempt to establish the function of to in relative clauses,

\footnotetext{
3 "Die Frage, wie der Komplex który to in Relativsätzen mit internem Nukleus zu analysieren ist, ist relativ eindeutig. Da das Element to in solchen Konstruktionen nicht weggelassen werden kann, muß die Folge który to als eine Einheit interpretiert werden. Der Ausdruck ist als eigenes Lexem, als weiteres Relativpronomen neben który, co etc. zu werten. Das Element to hat dann den Status eines Affixes, mit dem das Relativpronomen vom Fragepronomen który abgeleitet wird."
} 
interrogatives and adverbials. The numbering of sections and examples is continuous for both parts. ${ }^{4}$

\section{Restrictive and non-restrictive relative clauses in Polish}

\subsection{Restrictive and appositive clauses}

It is widely recognized that some languages have formal devices distinguishing restrictive and appositive relative clauses in writing, e.g. the choice of relativizer and punctuation, with the restrictive relative clause not being separated from the matrix clause by commas. In Polish this distinction is absent, since there is a prescriptive orthographic rule that has all subordinate clauses separated by commas. In addition, the same element heads both kinds of relative clauses, as can be seen in the following pair adapted from Mendoza (2010):

(10) Człowiek, którego wybrano burmistrzem, okazał się oszustem.

'The man whom they had elected mayor turned out to be a swindler.' (transl. JL-U)

(11) Jerzy, którego wybrano burmistrzem, okazał się oszustem.

'George, whom they had elected mayor, turned out to be a swindler.' (transl. JL-U)

While który is the default relative pronoun in Polish (cf. Grzegorczykowa 2004; Guz 2017), ${ }^{5}$ relative clauses referring to time or place can be introduced by uninflected kiedy 'when' and gdzie 'where' respectively. They tend to be appositive, though a restrictive reading is possible in some instances, as in (12) and in (13):

${ }^{4}$ A terminological remark is necessary here. In English-language literature there is a tendency to use term appositive with reference to typical non-restrictive clauses (cf. Cinque 2008; Citko 2016; de Vries 2005, among others). Following this terminological convention, I will be using the term 'non-restrictive' in a broader sense, i.e. with reference to any relative clause that is not restrictive.

${ }^{5}$ Relative clauses can be introduced by co (which in contrast to który does not inflect for gender, number and case), e.g.:

(i) Ci ludzie, którzy/co tu przychodzą...

'These people who/that come here' (Guz 2017: 3)

(ii) Te jabłka, które /co masz tu na stole

'These apples which/that you have here on the table' (Guz 2017: 3)

In contrast to który relatives, co relatives can bear a resumptive pronoun, coreferential with the head noun (cf. Guz 2017)

(iii) Ten nauczyciel, co go spotkateś.

this teacher co he_Acc meet_2 ${ }^{\text {nd }}$ Ps_SG_PAST

'This teacher you met.'

(adapted from Guz 2017:11) 
(12) Tęsknię za czasami, kiedy z wakacji przywoziło się rolkę filmu ORWO 36x24. (adapted from NKJP)

'I miss the times when one used to bring back a roll of ORWO' film $36 \times 24$ from one's holidays.' (transl. JL-U)

(13) Na zakończenie sezonu mamy jakieś lampki wina, sa kraje, gdzie wino podaje się do kolacji, nawet wśród sportowców. (adapted from NKJP)

'To end the season glasses of wine are served, there are countries where wine is served with dinner, even among the athletes.' (transl. JL-U)

They are nevertheless more frequent in appositive relative clauses, where the head is specific enough to block the restrictive reading:

(14) Z przystanku korzysta sporo ludzi [,] szczególnie w niedziele i święta, kiedy wracaja $z$ kościoła do domu. (adapted from NKJP)

'The [bus] stop is used by many people, particularly on Sundays and [religious] holidays, when they return home from church.' (transl. JL-U)

(15) Spektakl zaczyna się na schodach prowadzących do Teatru Wielkiego, gdzie zamiast kurtyny uniosly się w górę plansze ze scenami z przedstawienia. (adapted from NKJP)

'The show starts on the stairs leading to the Great Theater, where panels depicting scenes from the play have been raised instead of a curtain.' (transl. JL-U)

\section{2. 'Third kind' and degree relative clauses}

Beyond the restrictive vs. appositive dichotomy, there exists a whole array of relative clauses that do not restrict the scope of the head noun, yet they do not behave as appositives. Among them there are 'third kind' relatives, which include 'degree' relatives and 'kind' relatives, e.g. (16a-b) and (17) respectively:

(16a) Jack looked at the mice that there were in the cage. (de Vries 2005: 9) ${ }^{7}$

(16b) Jill spilled the milk that there was in the can. (de Vries 2005: 4)

(17) John is almost the doctor that /\#who/\#which his father was. (Grosu and Landman 1998: 150)

In English, both degree relatives and kind relatives obligatorily feature the complementizer that and not a $w h$-relative pronoun. It has been convincingly demonstrated that they cannot be considered restrictive. In the case of degree

\footnotetext{
${ }^{6}$ An East-German manufacturer of color films.

${ }^{7}$ Concerning this example de Vries (2005: 9) writes: "Notice that the meaning is not restrictive in the usual sense: there is no implied group of mice that is not in the cage; rather, the whole amount of mice in the domain of discourse is in the cage. In short, the relative clause contains a degree variable, which is maximalized upon." On the other hand, given the relativizer there and the punctuation, even though the whole amount of mice in the domain of discourse is in the cage, the relative clause cannot be considered appositive.
} 
relatives in English the evidence is provided by obligatory there. In other languages they are identified by a universal semantic-syntactic feature of disabling stacking, i.e. introducing a sequence of relative clauses that would jointly delimit the scope of the head (de Vries 2005: 9-10).

(18) Jack looked at the mice that there were in the cage ${ }^{*}$ that there had been freely walking in the house yesterday).

(de Vries 2005: 9-10)

In Polish, scope relatives with który cannot be formally distinguished from restrictive relatives. As a result, (19), that is a Polish rendering of (18), has both the restrictive and the degree reading:

(19) Jack przygląat się czterem myszom, które były w klatce.

'Jack looked at the four mice that (there) were in the cage.' (transl. JL-U)

On the restrictive reading the four mice are contrasted against some other mice outside the cage, and possibly in the same room, and under degree reading there is no suggestion of other mice being outside the cage (cf. footnote 7).

When który is substituted by jaki, the reading becomes exclusively that of degree since stacking is impossible with jaki, as seen in (20b).

(20a) Jack przygladat się czterem myszom, jakie były w klatce.

'Jack looked at the four mice that there were in the cage.' (transl. JL-U)

(20b) Jack przygladat się czterem myszom, jakie byly w klatce, ( ${ }^{\star}$ jakie wczoraj biegaty wolno po domu).

'Jack looked at the mice that there were in the cage ( ${ }^{*}$ that there had been freely walking in the house yesterday.)' (transl. JL-U)

In explicit kind relatives in Polish the presence of jaki and not of który is obligatory, as can be seen in Polish translation of (17), presented here as (21).

(21) Jan jest prawie takim lekarzem, jakim/*którym byt jego ojciec.

'John is almost the doctor that his father was.' (transl. JL-U)

The difference is even more notable in the negative versions of (21), i.e. (22a) and (22b) respectively:

(22a) Jan nie jest (takim) lekarzem, jakim był jego ojciec.

'John is not the doctor that his father was.' (transl. JL-U)

(22b) Jan nie jest ( ${ }^{*}$ takim) lekarzem, którym był jego ojciec.

'John is not a doctor, who his father was.' (transl. JL-U)

While (22a) gets a unique reading under which Jan is still a doctor, albeit somehow lacking in professional capacities in comparison to his father, $(22 \mathrm{~b})$ is only marginally acceptable with the relative clause getting appositive reading and 
parenthetical intonation. The meaning is that Jan did not follow his father's profession. ${ }^{8}$

The existence of jaki relative clauses has been noted in Przepiórkowski et al. (2002: 218-219). The analysis provided there follows Buttler et al. (1971: 375376), and accordingly kind relatives are dubbed rather misleadingly 'identifying-generalizing' (Polish: utożsamiająco-uogólniająca). Yet the examples provided by Przepiórkowski et al. constitute clear evidence that jaki-relatives are in fact kind relatives, e.g.:

(23a) to nie (taka) dziewczyna, jaka znałem

'it is not the girl that I used to know' (transl. JL-U)

Kind reading: it is the same person, but she has changed

(23b) to nie (ta) dziewczyna, która znałem

'it is not the girl I knew' (transl. JL-U)

Restrictive reading: it is a different person

(23c) widziałam faceta, jakiego byś polubił

'I saw a bloke that you would like' (transl. JL-U)

Kind reading: a person of a type you would like

(23d) widziałam faceta, którego byś polubił

'I saw a bloke that you would like' (transl. JL-U)

Restrictive reading: you would like this person

(23e) zobaczyłam twarz, jakiej się nie zapomina

'I saw a face that one does not forget' (transl. JL-U)

Kind reading: I saw an unforgettable face

(23f) zobaczyłam twarz, której nie zapomne

'I saw a face I will not forget' (transl. JL-U)

Restrictive reading: I will not forget that particular face

All the clauses described above, i.e. restrictive, appositive and 'third kind' clauses meet the semantic-syntactic criteria of relative clause: their meaning describes the nominal head.

\footnotetext{
${ }^{8}$ An anonymous reviewer is right saying that (22b) would be acceptable as part of a larger utterance, e.g. Jan nie jest takim lekarzem, jakim byt jego ojciec. Ojciec bowiem byt chirurgiem, a Jan jest okulista. 'Jan is not the same kind of doctor that his father was. The father was a surgeon, while Jan is an ophthalmologist.' In my opinion in such sequence takim needs to bear a contrastive sentence stress. This is one of several instances where my judgment of acceptability differs from that of the reviewer. For the lack of space, I cannot discuss all the partly amended examples provided by the reviewer.
} 


\subsection{Pseudo-relative clauses}

Besides relative clause patterns discussed above there is a second set of syntactic patterns, considered not relative clauses but pseudo-relative clauses. One sub-type has been recognized in the literature, e.g. Cinque (1996), Rafel (2001).

(24) Italian: Ho visto Mario che correva a tutta velocità.

French: J'ai vu Mario que courait a à toute Vitesse.

'I saw Mario that was running at great speed.' (Cinque 1996: 244)

(25) Spanish: He visto a María que corría.

'I saw Mary who was running.' (Rafel 2001: 3)

According to Rafel (2001: 3) pseudo-relative clauses (PR in the quote below) have certain characteristics that distinguish them from relatives:

(i) In the PR, the that-constituent does not modify the DP [i.e. determiner phrase], but it rather expresses a situation in which that DP is a participant. This is what allows the whole construction to express an event in progress.

[...]

(iii) Differently from a relative clause, the DP can only be interpreted as (or associated with) the subject of the embedded finite verb.

(iv) The tense of the that-constituent must match the tense of the matrix clause only in the PR.

(v) And only in the PR the DP can be extracted leaving the that-constituent behind.

Cinque (1996) and Rafel (2001) recognize the existence of pseudo-relatives in Romance languages and in English. However, pseudo-relatives of this type are also available in Polish, e.g.:

(26) Widziałam Marię, która biegła co sił w nogach.

'I saw Mary who was running as fast as she could.' (transl. JL-U)

Despite the presence of a proper name, the relative clause in (26) cannot be considered appositive, since it can be negated when the matrix clause is negated, e.g.:

(27) Nie widziałam Marii, która biegła co sił w nogach.

'I did not see Mary who was running as fast as she could.' (transl. JL-U)

1. I did not see Mary at all, though she was running at that time.

2. I did see Mary, but she was not running at that time.

One of the defining features of pseudo-relative clauses discussed so far is its tense specification matching the tense in the matrix clause. In fact, the observed event described in the pseudo-relative and the act of observation described in the matrix clause need to be simultaneous. Yet there is another type 
of relative-like clauses in which, in spite of the formal matching of tenses in both clauses, the subordinate clause describes a subsequent event, e.g.: 9

(28) They invited John, who accepted/refused the invitation.

As I have demonstrated in Linde-Usiekniewicz (2012: 181), these are not appositive relative clauses, since they cannot preserve the subordinate clause when the matrix is negated. Thus, negating them leads to incoherence:

(29) *They did not invite John, who accepted/refused the invitation.

This type of który subordinate clause is present in Polish, as can be seen in (30) and (31), which are direct translations of (28) and (29), respectively.

(30) Zaprosili Jana, który przyjął/odrzucił zaproszenie. (=(28), transl. JL-U)

(31) * Nie zaprosili Jana, który przyjął/odrzucił zaproszenie. (=(29) transl. JL-U)

In contrast to the first type of pseudo-relatives, in pseudo-relatives describing subsequent events, the relativizer need not be associated with the subject of the finite verb in the subordinate clause (cf. point (iii) in the quote from Rafel 2001 above), e.g.:

(32) Zaprosili Jana, którego ten fakt bardzo ucieszyt.

'They invited John, whom this fact greatly pleased.'

As rightly noted by Grzegorczykowa (2004: 119), such clauses, which she identifies as pseudo-relative as well (Polish: pozornie względne), do not provide further characteristics of the apparent head, but they contain information about a subsequent event. In addition, they may also resemble restrictive, and not appositive relative clauses, since the noun in the matrix clause does not need to be a proper name, though an appositive reading is also available:

(33) Weszli do pokoju, w którym rozpoczęto rozmowę.

'They entered a/the room, in which the conversation began.' (transl. JL-U)

Consecutive reading: they $y_{i}$ entered the room in which they $y_{i}$ started the conversation

'They entered a/the room in which the conversation had begun.' (transl. JL-U)

Restrictive reading: they ${ }_{i}$ entered the room in which they had started the conversation 'They entered the room, in which the conversation had begun.' (transl. JL-U)

Appositive reading: they ${ }_{i}$ entered the room, in which they ${ }_{j}$ had started the conversation (adapted from Grzegorczykowa 2004: 119)

The ambiguity between relative and pseudo-relative readings of (33) is due to the referential ambiguity of the verb form rozpoczęto, considered impersonal

\footnotetext{
${ }^{9}$ This example is partly similar in content to Citko's (2016: 88): John, who/ ${ }^{\star}$ that $/{ }^{\star} \varnothing$ got the offer, will probably refuse, but the division of content between matrix and subordinate clauses is the reverse.
} 
in Polish. The function of this finite form is to underspecify the identity of the external argument of the verb (Bogusławski 1984) while maintaining an active structure of the clause. In the pseudo-relative reading, the tacit external argument of the impersonal verb form has to be identical with the subject of the matrix clause, while in the restrictive and appositive relative readings it cannot.

If the matrix clause is negated, the sentence is not incoherent, but it acquires either a restrictive or an appositive reading, yet in both cases the people who enter are not the same as the people who talk, and the beginning of the conversation is no longer subsequent to the act of entrance:

(34) Nie weszli do pokoju, w którym rozpoczęto rozmowę.

'They did not enter the room in which the conversation had begun.' (transl. JL-U) Restrictive reading: they ${ }_{1}$ did not enter the room in which they ${ }_{2}$ had begun the conversation

'They did not enter the room, in which the conversation had begun.' (transl. JL-U) Appositive reading: they ${ }_{1}$ did not enter the room, in which they ${ }_{2}$ had begun the conversation

\section{Types of appositive relative clauses}

In the previous section, which has focused on relative and pseudo-relative clauses that cannot be considered either restrictive or appositive, the latter have been presented as if they were quite uniform. This, however, is not the case.

First of all, there is a distinction proposed by Cinque (2008) between integrated and unintegrated appositive relative clauses. ${ }^{10}$ This distinction is marked formally in Italian (Cinque 2008) by the choice of che/cui complementizer/relativizer in the former and il quale relativizer in the latter ${ }^{11}$ :

(35) Inviterò anche Giorgio, che/il quale abita li vicino.

'I will invite also G., that/who lives nearby'.

(adapted from Cinque 2008: 100-101)

Il quale relatives share some of their syntactic properties with che/cui relatives, which are therefore immaterial for the distinction here, yet there is a set of features that are proper to il quale relatives only. ${ }^{12}$ These are:

${ }^{10}$ The sense of the term 'unintegrated' as used by Cinque should not be confused with the sense it is given in studies of spontaneous speech (cf. Guz 2017 and the literature cited therein).

${ }^{11}$ The distinction between che and cui, amply discussed in the work cited, is immaterial here.

${ }^{12}$ In fact, these semantic-syntactic features are applied universally to distinguish between integrated and unintegrated appositive relative clauses in general (Cinque 2008; Citko 2016). 


\subsection{Heavy pied-piping}

(36) Inviterò anche Giorgio, il fratello del quale è uno dei nostri più cari amici. *Inviterò anche Giorgio, il fratello di cui è uno dei nostri più cari amici. 'I will invite also G., the brother of whom is one of our dearest friends.' (Cinque 2008: 101)

\subsection{Allowing for non-declaratives in the relative}

(37) Ci sono poi i Rossi, per i quali, ti prego, cerca di trovare una sistemazione al più presto. ${ }^{*}$ Ci sono poi i Rossi, per cui, ti prego, cerca di trovare una sistemazione al più presto. 'There are then the R.'s, for whom please try to find an accommodation as soon as possible.'

(adapted from Cinque 2008: 103)

\subsection{Non-adjacency to the head}

(38) Da quando i russi se ne sono andati, i quali non si erano mai veramente integrati con la popolazione, la pace è finita.

${ }^{*}$ Da quando i russi se ne sono andati, che non si erano mai veramente integrati con la popolazione, la pace è finita.

'Since the Russians left, who never really intermingled with the population, there is no more peace.'

(adapted from Cinque 2008: 103)

\subsection{Split antecedents}

(39) Se Carlo non amava più Anna , $_{\mathrm{j}}$ i quali $i_{\mathrm{i}, \mathrm{j}}$ d'altra parte non si erano mai voluti veramente bene, una ragione c'era.

'If C. was no longer in love with A., who at any rate never really loved each other, there was a motive.'

(Cinque 2008: 104)

\subsection{Internal heads and lack of identity between internal and external head}

(40) Questo farmaco, col quale farmaco il Ministero intende iniziare la sperimentazione, è il frutto di molti anni di lavoro.

'This medicine, with $\mathrm{w}[\mathrm{h}] \mathrm{ich}$ medicine the Ministry intends to begin the experiment, is the result of many years' work.'

(Cinque 2008: 105)

(41) Ha raggiunto la fama con "Il giardino dei Finzi-Contini", il quale romanzo ha poi anche avuto una riduzione cinematografica.

'He became famous with Il giardino dei Finzi-Contini, which novel was then also made into a film.'

(Cinque 2008: 105) 
In addition, il quale relatives, which are normally marked for gender and number that has to match the gender and number of the head, allow for such mismatch, e.g.:

(42) Non era certo un romanziere, la prima virtù dei quali è quella di catturare l'interesse del lettore.

'He was no novelist (sing.), the first virtue of whom (pl.) is that of catching the reader's interest.'

(Cinque 2008: 106)

(43) Il Cairo, la quale ${ }^{*}$ il quale è la capitale dell'Egitto,...

'(Lit.) the (masc.) Cairo, the which (fem./*masc.) is the capital city of Egypt',

(Cinque 2008: 106, adapted gloss)

In the second part of his paper Cinque applies the criteria that distinguish integrated and unintegrated appositive relative clauses and demonstrates that English appositive relative clauses are in fact unintegrated, while Chinese appositive relatives are integrated. Citko (2016) applies the same criteria to Polish and arrives at the conclusion that Polish appositive relative clauses are unintegrated, similarly to English ones.

The distinction between integrated and unintegrated appositive relative clauses, as presented above, is made on almost purely syntactic grounds and leads both Cinque and Citko to propose different models for derivation of each type of relative clauses within a generative framework. Almost no attention is paid to the possible semantic distinctions between the two types, even though in some contexts both types are possible (cf. Cinque 2008). While for both types of pseudo-relative clauses discussed above there is a strong semantic constraint on the content of the pseudo-relatives (and in the case of simultaneous pseudo-relatives on the form as well), there seems to be no such constraint on appositive relative clauses. Though in most instances their content contributes to the discourse (cf. Loock 2007), such contributions are varied and there may be no formulable constraints on their semantic purport. In fact, appositive relative clauses can contain material that is relevant to the speaker and possibly their audience, but not to the matter at hand, e.g.:

(44) Stephen Lawrence's mother yesterday warned that it could take more than one generation to implement the changes stemming from the inquiry into her son's racist murder. Doreen Lawrence spoke at the inaugural Stephen Lawrence memorial lecture, delivered by the Prince of Wales. Her son, who was 18 in 1993 when stabbed to death at a bus stop, had dreamed of becoming an architect, and the prince used his speech to announce a scholarship named after him aimed at increasing ethnic minority architects. (adapted from Loock 2007: 351-352)

(45) When Steven Soderbergh, who has already directed Clooney in "Out of Sight", phoned to tell me he was planning to do a remake of the film, I jumped for joy.

(adapted from Loock 2007: 346) 
Moreover, it is possible to construct a sentence with an appositive relative clause semantically unconnected to the matrix, although they may be quite rare in naturalistic data, since actual speakers may be quite reluctant to bring such extraneous material into their discourse.

(46) Janek, który urodził się w piątek//ubiera się na różowo//biega w maratonach//...//, studiuje matematykę.

'John, who was born on a Friday//dresses in pink//runs in marathons//..., studies mathematics.' (transl. JL-U)

On the other hand, appositive relatives can contain material crucial to the meaning of the entire utterance.

(47) C. Dyas (...) confirmed that the blood donated by the seven $v$ CJD victims was taken before 1999, when the authority introduced new safety procedures designed to remove prions, the infectious proteins thought to transmit $v C J D$.

(Loock 2007: 347)

To distinguish between the two situations, I will call those appositive relative clauses in which the content is crucial to the utterance 'at-issue' appositives, however contradictory the term sounds, and those where it is not will be referred to as 'parenthetical' appositives. ${ }^{13}$ It is quite possible that on purely semantic and discourse grounds there is no clear-cut distinction between the two, and there may simply be a cline of 'at-issue-ness', from clearly parenthetical, as in (46) to strongly at issue as in (47), with (44) and (45) falling somewhere in-between.

Wrapping up: in some languages it is possible to distinguish integrated and unintegrated appositive relative clauses on the basis of their syntax, e.g. in Italian. Other languages apparently only possess one kind of appositive relatives: either only unintegrated, as English and presumably Polish, or only integrated, as Chinese. Among unintegrated appositive clauses one finds those with internal head besides the external one. On the other hand, on the semantic grounds, the distinction can be made between 'at-issue' appositives and parenthetical appositives. Languages with unintegrated appositive clauses seem to possess

${ }^{13}$ The term 'at issue' has been borrowed from AnderBois et al. (2010) though with a radically different interpretation from the one Authors give and which is generally understood when the notion is discussed (cf. Koev 2018). As Koev (2018) puts it: "At-issue content must then have at least two properties. First, it is primary or carries the main theme of discourse. This property is often expressed by saying that at-issue content is relevant to the discourse topic or the question under discussion. Second, at-issue content is what is being negotiated among interlocutors before it is added to the common ground". As a consequence, there is one type of at-issue-ness that is associated with assertion (Koev 2018), and that is the sense discussed in AnderBois et al. (2010), who contrast it explicitly with 'appositive' (as can be seen from the title of their paper.) In my usage here at-issue-ness becomes a feature of an otherwise appositive clause. Such possibility has been noted by Simons (2007), who though does not use the term 'at issue', yet presents a strong case for the content of an appositive relative clause being as important to the purport of an utterance as that of the matrix clause, with a most telling example Jane, who once supported the Republicans, is now a committed Democrat (Simons 2007: 1053). 
both semantic kinds, since relevant examples can be easily rendered in Polish, and possibly most Romance languages.

\section{Wh-to and wh-to-less relative and pseudo-relative clauses in Polish}

In the previous two sections I have focused on a syntactic-semantic typology of relative clauses (including pseudo-relative clauses) available in Polish. As could be seen from the examples above, and as is confirmed in literature (Mendoza 2010; Linde-Usiekniewicz in print), only double headed appositive relative clauses obligatorily bear the to segment. Yet it has been noted that at least który appositive relatives without internal heads have a który to variant (compare (3) and (4) in the Introduction). Since the morphosyntactic nature of to remains yet to be ascertained (see Mendoza 2010 and Topolińska 1984 cited in the Introduction) for the time being, I will be referring to it simply as a 'segment'.

This section addresses two issues. One is the existence of to-bearing counterparts of wh-relative and pseudo-relative clauses. The other is how the presence of the segment to affects available readings, discussed in the previous section, i.e. the restrictive vs. appositive vs. 'third kind' relative reading and relative vs. pseudo-relative reading. More fine-grained semantic distinctions between to-bearing and to-less appositive relative clauses will be addressed in Part Two (Section 4)

First of all, restrictive relative clauses never bear to. Thus while (10), repeated here for convenience as (47) is ambiguous, (48) is not:

(47) Człowiek, którego wybrano burmistrzem, okazał się oszustem.

Restrictive: 'The man whom they had elected mayor turned out to be a swindler.' Appositive: 'The man, whom they had elected mayor, turned out to be a swindler.'

(48) Człowiek, którego to wybrano burmistrzem, okazał się oszustem

Appositive only: 'The man, whom they had elected mayor, turned out to be a swindler.'

The situation is more complex in 'third kind' relatives and there is an observable difference between degree and kind relatives. It seems that if the segment to is introduced in relatives with który, which are ambiguous as to degree vs. restrictive reading, neither degree reading nor restrictive reading is available any longer, and the only possible interpretation is appositive, e.g.:

(49) Jack przyglądał się czterem myszom, które to były w klatce.

Appositive reading: 'Jack looked at the four mice, which were in the cage.'

In degree relatives with jaki, which are never ambiguous between restrictive and non-restrictive, the segment to seems unacceptable: 
(50) ${ }^{*} J a c k$ przygladat się czterem myszom, jakie to były $w$ klatce.

'Jack looked at the four mice that there were in the cage.'

In some, but not all kind relatives with jaki, however, to can appear, e.g. it is acceptable in (51) and (52), but not-in (53a-c), which represent to-bearing versions of kind relatives presented in (23):

(51) Jan jest prawie takim lekarzem, jakim to był jego ojciec.

'John is almost the doctor that his father was.'

(52) Jan nie jest (takim) lekarzem, jakim to byt jego ojciec.

'John is not the doctor that his father was.'

(53a) ${ }^{*}$ to nie (taka) dziewczyna, jaka to znałem

'it is not the girl that I used to know'

Kind reading: it is the same person, but she has changed

(53b) * widziałam faceta, jakiego to byś polubił

'I saw a bloke that you would like'

Kind reading: a person of a type you would like

(53c) ?zobaczyłam twarz, jakiej to sie nie zapomina

'I saw a face that one does not forget'

Kind reading: an unforgettable face

The constraint appears to be semantic in nature and related to the sense of the noun in the matrix clause. Roughly, to is acceptable whenever the noun is used as a predicate, but in addition, it cannot be used referentially, but it must be used adscriptively (see Hengeveld 2008 for the distinction.). In (53a-c) the nouns are both used referentially, and in (53b-c), they are arguments as well. The difference between jaki and jaki to kind relatives will be further elaborated on below.

The two kinds of pseudo-relative clauses identified above behave differently with respect to który to. In the case of simultaneous pseudo-relatives, even if all semantic and syntactic conditions are met, i.e. there is an observation verb in the matrix clause, the subordinate clause refers to an event in progress, and the relativizer is associated with the subject of the subordinate clause, if the subordinate clause is introduced by który to, it no longer receives a pseudo-relative reading, but an appositive one. This is seen clearly in instances with negated matrix clause, e.g. in (54), which is a modified version of (27) from Section 1. Here the subordinate clause falls outside the scope of negation, as is the general case of appositive relative clauses:

(54) Nie widziałam Marii, która to biegła co sił w nogach.

'I did not see Mary, who was running as fast as she could.'

Intended meaning: 'Mary was running but I did not see her'

The consecutive pseudo-relative clauses that resemble appositive relative clauses because they bear a proper noun in the matrix case, maintain their 
pseudo-relative meaning with the subordinate clause bearing to, as can be seen in (55)-(57) (modified versions of (30)-(32) from Section 1:

(55) Zaprosili Jana, który to przyjął/odrzucił zaproszenie.

'They invited John, who accepted/refused the invitation.' (transl. JL-U)

(56) * Nie zaprosili Jana, który to przyjąt/odrzucił zaproszenie.

'They did not invite John, who accepted/refused the invitation.' (transl. JL-U)

(57) Zaprosili Jana, którego to ten fakt bardzo ucieszyt.

'They invited John, whom this fact greatly pleased.' (transl. JL-U)

By contrast, consecutive pseudo-relatives that resemble restrictive relatives and may have a restrictive reading, lose the restrictive reading in favor of an appositive one, but they maintain the consecutive pseudo-relative reading. It can be easily seen in (58) (a modified version of (33) from Section 1):

(58) Weszli do pokoju, w którym to rozpoczęto rozmowę.

'They entered a/the room, in which the conversation began.'

Consecutive reading: they $y_{i}$ entered the room in which they ${ }_{i}$ began the conversation

'They entered the room, in which the conversation had begun.'

Appositive reading: they ${ }_{i}$ entered the room in which they ${ }_{j}$ had begun the conversation

\section{Closing remarks}

Part One of the paper has presented a broad picture of relative clauses identified in theoretical literature and addressed the question which types of relative clauses discussed in the literature can be find in Polish. In addition, the impact of to following the relativizer has been discussed.

Regarding the default relativizer który it has been shown that while Polish relative clauses with który can be interpreted as restrictive, appositive, 'third kind' or pseudo-relatives, który to relatives are uniquely appositive. In addition, only który to, and not który alone can appear in appositive relative clauses with internal heads.

While 'third kind' degree relative clauses with jaki are possible, they are not possible with jaki to. With kind relatives the situation is more complex and the acceptability of jaki to depends on the semantic nature of the head noun. In addition, when possible, jaki to suggests that the characteristics implied by the entire predicative nominal phrase (including the kind relative) have been given some attention in previous discourse or at least are assumed by the speaker to be known by the audience. ${ }^{14}$ Thus (51) and (52), repeated here for con-

\footnotetext{
${ }^{14}$ The way the impact of to is framed here may be seen as an indirect reference in Relevance Theory (Sperber and Wilson 1986). Though my thinking about to has been thus influenced, the paper does not attempt to analyze the segment to in terms of RT.
} 
venience, are likely to be uttered after professional qualities of Jan's father have been discussed, or at least have been indirectly invoked.

(51) Jan jest prawie takim lekarzem, jakim to był jego ojciec.

'John is almost the doctor that his father was.'

(52) Jan nie jest (takim) lekarzem, jakim to byt jego ojciec.

'John is not the doctor that his father was.'

Part Two will begin with a closer look at the difference between to-bearing and to-less appositive clauses. It will also extend the analysis to include the role of to in clauses with relativizers kiedy 'when' and gdzie 'where'. Next the question of the role of to attached to wh-conjunctions kiedy 'when' and gdzie 'where' in wh-adverbials, and the role of to attached to the interrogative pronoun in $w h$ interrogatives will be addressed. Finally, the possibility of linking the all the observed effects (i.e. in $w h$-relative clauses, $w h$-adverbial clauses and $w h$-interrogatives) to a single element to will be discussed.

\section{References}

AnderBois Scott, Brasoveanu Adrian, Henderson Robert (2010). Crossing the appositive/at-issue meaning boundary. Proceedings of SALT 20, 328-346.

BAŃko Mirosław (2013). Porada z dnia 5.12.2013. [https://sjp.pwn.pl/poradnia/haslo/ ktory-to;14742.htm; accessed August 12, 2018].

BogusŁawski Andrzej (1984). Polskie nieidentyfikacyjne wyrażenia osobowo-referencjalne. Polonica 10, 49-69.

Buttler Danuta, Kurkowska Halina, Satkiewicz Halina (1971). Kultura języka polskiego: zagadnienia poprawności gramatycznej [Polish Grammar and Style: Grammatical Correctness]. Warszawa: Wydawnictwo Naukowe PWN.

CINQUE Guglielmo (1996). The pseudo-relative and acc-ing constructions after verbs of perception. In Italian Syntax and Universal Grammar, 244-275, Cambridge: Cambridge University Press.

Cinque Gugliemo (2008). Two types of non-restrictive relatives. In Empirical Issues in Syntax and Semantics 7, Olivier Bonami, Patricia Cabredo Hofherr (eds.), 99-137. [http://www.cssp.cnrs.fr/eiss7/cinque-eiss7.pdf; accessed July 26, 2018].

Сітко Barbara (2016). Types of appositive relative clauses in Polish. Studies in Polish Linguistics 11 (3), 85-85.

Dobaczewski Adam (2018). Powtórzenie jako zjawisko tekstowe i systemowe. Repetycje, reduplikacje i quasi-tautologie w jezyku polskim. [Iteration as a Textual and Systemic Phenomenon: Repetitions, Reduplications in Quasi-Tautologies in Polish] Toruń: Wydawnictwo Naukowe Uniwersytetu Mikołaja Kopernika.

Grosu Alexander, LANDman Fred (1998). Strange relatives of the third kind. Natural Language Semantics 6 (2), 125-170.

Grzegorczykowa Renata (2004). Wykłady z polskiej składni. [Lectures in Polish Syntax] Warsaw: Wydawnictwo Naukowe PWN. 
Guz Wojciech (2017). Wh-pronoun and complementizer relative clauses: unintegration features in conversational Polish. Studies in Polish Linguistics 11(3), 1-26.

Hengeveld Kees (2008). Prototypical and non-prototypical noun phrases in Functional Discourse Grammar. In The Noun Phrase in Functional Discourse Grammar, Daniel García Velasco, Jan Rijkhoff (eds.), 43-63. Berlin - New York: Mouton de Gruyter.

Koev Todor (2018). Notions of at-issueness. Language and Linguistic Compass 12 (2) [https://doi.org/10.1111/lnc3.12306; accessed August 25, 2019].

Linde-UsiekniewiCz Jadwiga (2012). From Conflict Through Compromise to Collaboration: Semantics, Syntax and Information Structure in Natural Languages, Warsaw: Nakładem Wydziału Polonistyki

LiNde-UsiekniewiCz Jadwiga (in print) Polskie zdania względne $\mathrm{z}$ wewnętrznym rzeczownikiem - wstępne rozpoznanie. Poradnik Językowy.

Loock Rudy (2007). Appositive relative clauses and their functions in discourse. Journal of Pragmatics 39, 336-362.

Mendoza Imke (2010). Relativsätze mit który to. Wiener Slawistischer Almanach 65, 105-118.

NKJP: Narodowy Korpus Języka Polskiego. http://nkjp.pl/ [accessed November 10, 2018]

Przepiórkowski Adam, Kupść Anna, Marciniak Małgorzata, Myкowiecka Agnieszka (2002) Formalny opis języka polskiego: teoria i implementacja. [Formal Description of Polish: Theory and Implementation],Warsaw: Akademicka Oficyna Wydawnicza EXIT.

RAFEL Joan (2001). The syntax of small clause predication. In Syntax of Predication. Proceedings of $6^{\text {th }}$ Workshop on Syntax of Predication Nov. 2-3, 2001, ZAS-Berlin, Niina ZhANG (ed.), 153-170. Berlin: ZAS.

Simons Mandy (2007). Observations on embedding verbs, evidentiality, and presupposition. Lingua 117(6), 1034-1056.

SP XVI : Słownik polszczyzny XVI wieku, digital version, [https://spxvi.edu.pl/wersjacyfrowa; accessed August 12, 2018].

Sperber Dan, Wilson Deidre (1986). Relevance: Communication and Cognition. Oxford: Blackwell.

Topolińska Zuzanna (1984). Składnia grupy imiennej. In Gramatyka współczesnego języka polskiego. Składnia [Grammar of Contemporary Polish. Syntax], Maciej Grochowski, Stanisław Karolak, Zuzanna Topolińska (eds.), 301-389. Warsaw, Wydawnictwo Naukowe PWN.

de VRIEs Mark (2005). The fall and rise of universals on relativization. Journal of Universal Language 6, 1-33.

Jadwiga Linde-Usiekniewicz

Katedra Językoznawstwa Ogólnego, Wschodnioazjatyckiego Porównawczego

i Bałtystyki

Wydział Polonistyki

Uniwersytet Warszawski

Krakowskie Przedmieście 26/28

00-927 Warszawa

jlinde(at)uw.edu.pl 
